\title{
Aerosol Delivery Device Selection for Spontaneously Breathing Patients: 2012
}

\author{
Arzu Ari PhD RRT PT CPFT FAARC and Ruben D Restrepo MD RRT FAARC
}

\begin{abstract}
Using an electronic literature search for published articles indexed in PubMed between January 1990 and August 2011, the update of this clinical practice guideline is the result of reviewing 84 clinical trials, 54 reviews, 25 in vitro studies, and 7 evidence-based guidelines. The recommendations below are made following the Grading of Recommendations Assessment, Development, and Evaluation (GRADE) criteria: 1: It is recommended that selection of the appropriate aerosol generator and interface be made based on the patient's age, physical and cognitive ability, cost, and the availability of the prescribed drug for use with a specific device. 2: Nebulizers and pressurized metered-dose inhalers (pMDIs) with valved holding chambers are suggested for use with children $\leq 4$ years of age and adults who cannot coordinate the use of pMDI or dry-powder inhaler (DPI). 3: It is suggested that administration of aerosols with DPIs be restricted to patients $\geq 4$ years of age who can demonstrate sufficient flow for the specific inhaler. 4: For patients who cannot correctly use a mouthpiece, aerosol masks are suggested as the interface of choice. 5: It is suggested that blow-by not be used for aerosol administration. 6: It is suggested that aerosol therapy be administered with a relaxed and nondistressed breathing pattern. 7: Unit dose medications are suggested to reduce the risk of infection. 8: It is suggested that nebulizer/drug combinations should be used as approved by the FDA. 9: It is recommended that healthcare providers know the correct use of aerosol generators; they should teach and periodically re-teach patients about how to use aerosol devices correctly. 10: It is suggested that intermittent positive-pressure breathing should not be used for aerosol therapy. 11: It is recommended that either nebulizer or pMDI can be used for aerosol delivery during noninvasive ventilation. Key words: aerosol; dry-powder inhaler; metereddose inhaler; nebulizer; patient education; patient adherence; noninvasive ventilation; device selection. [Respir Care 2012;57(4):613-626. () 2012 Daedalus Enterprises]
\end{abstract}

\section{ADS 1.0 DESCRIPTION}

Effective administration of aerosolized medications depends on the patient's age, physical and cognitive ability,

\footnotetext{
Arzu Ari PhD RRT PT CPFT FAARC is affiliated with the Division of Respiratory Therapy, Georgia State University, Atlanta, Georgia. Ruben D Restrepo MD RRT FAARC is affiliated with the Department of Respiratory Care, The University of Texas Health Sciences Center at San Antonio, San Antonio, Texas.

The authors have disclosed no conflicts of interest.
}

Correspondence: Arzu Ari PhD RRT PT CPFT FAARC, Division of Respiratory Therapy, School of Health Professions, Georgia State University, PO Box 4019, Atlanta GA 30302-4019. E-mail: arzuari@ hotmail.com.

DOI: $10.4187 /$ respcare.01756 the delivery system, and the patient-device interface..$^{1-7}$ Physical ability means the patient's ability to use a specific device, based on factors such as inspiratory volumes and flows, hand-breath coordination, or ability to use a mouthpiece. Cognitive ability indicates the patient's understanding of how and when to use a device and medication. ${ }^{8-10}$ Airway size, respiratory rate, inspiratory flow rate, and breathing pattern create substantial challenges for effective aerosol delivery. ${ }^{4,5,8-12}$ While most aerosol generators can be used with all age groups, special consideration should be given to young children because they cannot master the complex steps required for adequate delivery of aerosol treatments. ${ }^{8,9,13}$ A mouthpiece may be used for patients $\geq 3$ years who are able to cooperate, ${ }^{8,10,14}$ while a face mask is recommended for patients who cannot use a mouthpiece. ${ }^{2,3,8,9,14-17}$ Face masks should be properly fitted with minimal leak, particularly avoiding aerosol deliv- 
Table 1. Age Guidelines for Use of Aerosol Delivery Device Types $^{3,8,9,14,39}$

\begin{tabular}{lc}
\hline \hline \multicolumn{1}{c}{ Aerosol Device and Interface } & Age \\
\hline Small-volume nebulizer with mask or hood & Infants \\
Small-volume nebulizer with mask & $\leq 3 \mathrm{y}$ \\
Small-volume nebulizer with mouthpiece & $\geq 3 \mathrm{y}$ \\
pMDI with valved holding chamber/spacer and mask & $<4 \mathrm{y}$ \\
pMDI with valved holding chamber/spacer & $\geq 4 \mathrm{y}$ \\
DPI & $\geq 4 \mathrm{y}$ \\
MDI & $\geq 5 \mathrm{y}$ \\
Breath-actuated MDI (eg. Autohaler) & $\geq 5 \mathrm{y}$ \\
Breath-actuated nebulizer & $\geq 5 \mathrm{y}$
\end{tabular}

$\overline{\mathrm{pMDI}}=$ pressurized metered-dose inhaler

DPI $=$ dry powder inhaler

ery into the eyes, to optimize inhaled dose. ${ }^{18-24}$ Aerosol generators are equally efficacious if they are age appropriate and used correctly. ${ }^{25-39}$ Regardless of age, patients need to demonstrate ability to seal the lips around the mouthpiece and ability to generate sufficient flow for the specific inhaler. Table 1 provides age guidelines for use of aerosol delivery device types.

This clinical practice guideline (CPG) addresses the selection of an aerosol delivery device for the administration of inhaled medications by small-volume nebulizer (SVN), large-volume nebulizer (LVN), pressurized metered-dose inhaler (pMDI), and dry-powder inhaler (DPI) to spontaneously breathing patients without an artificial airway. Studies on spontaneously breathing patients with tracheostomy were excluded from this CPG, due to lack of evidence in this area of research. Using an electronic literature search for published articles indexed in PubMed between January 1990 and August 2011, the update of this CPG is result of reviewing 84 clinical trials, 54 reviews, 25 in vitro studies, and 7 evidence-based guidelines. The search terms used in this CPG include nebulizer, dry-powder inhaler, metered-dose inhaler, aerosol, face mask, mouthpiece, hood, blow-by, valved holding chamber (VHC), spacer, patient education, patient adherence, noninvasive ventilation, and device selection.

1.1 Small-Volume Nebulizer. SVNs are divided into 3 types: jet nebulizer, mesh nebulizer, and ultrasonic nebulizer. The jet nebulizer is powered by a compressed gas source, in the form of a compressor or hospital pressurized gas source such as piped medical gas or high pressure tanks. The medication is displaced up a capillary tube from the nebulizer's reservoir and is dispersed continuously as aerosolized particles. ${ }^{14,40-43}$ There are 4 types of jet nebulizer: jet nebulizer with reservoir tube, jet nebulizer with collection bag, breath-actuated jet nebulizer, and breath- enhanced jet nebulizer. Jet nebulizer with reservoir tube is the most commonly used and generates continuous aerosol during the entire breathing cycle. Jet nebulizer with a reservoir bag collects aerosol leaving the jet nebulizer when patient is not inhaling. Thus, it increases dose efficiency by delivering aerosol in the reservoir bag with the next inspiration. While the breath-actuated jet nebulizer generates aerosol only during inspiration, which reduces loss of medication during expiration, the breath-enhanced jet nebulizer uses one-way valves to prevent the loss of aerosol to the environment and to increase aerosol delivery to the patient. Mesh nebulizer is powered by electricity to create aerosol by way of an aperture plate or an ultrasonic horn. The diameter of the mesh or aperture determines the size of the particle generated. ${ }^{14,44-46}$ Ultrasonic nebulizer is also powered by electricity to create high frequency vibrations in a piezo crystal, which are transferred to the surface of the solution, creating a standing wave that generates aerosol. ${ }^{14}$

The aerosolized particles are inhaled by the patient or delivered in conjunction with positive-pressure breaths such as intermittent positive-pressure breathing, noninvasive ventilation (NIV), and intrapulmonary percussive ventilation. Whereas aerosol delivery via SVN with intermittent positive-pressure breathing is less efficient than SVN alone, ${ }^{47}$ using NIV for aerosol therapy is feasible and effective in improving bronchospasm. ${ }^{48-52}$ However, it should be noted that aerosol delivery with NIV is influenced by the NIV settings, the leak port position, the type of aerosol generator, and the interface used during the treatment. ${ }^{53-55}$ For instance, increasing the inspiratory pressure during NIV increases aerosol deposition, as opposed to increased expiratory pressure, which decreases aerosol delivery. ${ }^{53}$ The efficiency of an aerosol generator is influenced by the location of the leak port. If the leak port is distal to the device, drug delivery is greater than at the proximal location, regardless of the type of aerosol generator used. ${ }^{54,55}$ Consequently, drug delivery via mask with a leak port is less than that without. If the leak port is in the mask, the efficiency of pMDI is better than that of nebulizer because aerosol loss with pMDI during expiration is less, compared to the nebulizer. According to a recent in vitro comparison, aerosol deposition with mesh nebulizer is significantly greater, compared to the jet nebulizer during NIV. ${ }^{55}$ Also, the use of nebulization with NIV is better than nebulization alone in some patients. ${ }^{52}$ The intrapulmonary percussive ventilator is primarily an airway clearance device, but it is usually combined with a nebulizer, although its physiologic and clinical effects have not been studied extensively. Studies have shown that aerosol deposition with the intrapulmonary percussive ventilator is significantly lower than with a standard nebulizer alone and has large inter-individual variability. ${ }^{56,57}$ 
1.2 Large-Volume Nebulizer. LVNs with a fill volume $>10 \mathrm{~mL}$, powered by a compressed gas source, are utilized to administer continuous aerosol delivery over a prolonged period of time. Due to changes in drug concentration over time, LVNs should be emptied and refilled at 5 hours. ${ }^{58}$ An alternative approach for continuous nebulization is small volume jet or mesh nebulizer with infusion pump. Regardless of the type of nebulizer utilized, a face mask is typically used as the interface for continuous nebulization. Previous studies reported that continuous inhaled bronchodilator administration is safe, effective, and less time consuming, when compared with intermittent nebulization in patients with severe asthma. ${ }^{59-61}$ Continuous bronchodilator delivery is the most common aerosol treatment for continuous nebulization. ${ }^{62,63}$

1.3 Pressurized Metered-Dose Inhaler. There are 2 types of pMDI: conventional and breath-actuated. Both include a canister, propellants, drug formulary, metering valve, and actuator. Actuation of the pMDI results in the ejection of one dose of aerosolized medication. ${ }^{64}$ The conventional pMDI has a press-andinhale design, whereas the breath-actuated pMDI eliminates the need for hand-breath coordination. A simple spacer attached to the pMDI enhances aerosol delivery by decreasing the velocity of the particles and the number of large particles, thus reducing oropharyngeal deposition. ${ }^{65,66} \mathrm{~A}$ spacer without valves requires coordination between inhalation and actuation and is not suitable for patients with poor hand-breath coordination; a VHC is more desirable in this setting. Electrostatic charge can decrease aerosol delivery unless it is washed with soap and water, or, alternatively, a non-electrostatic device can be used without the need for pretreatment. ${ }^{66-69}$ Use of breath-actuated pMDI in children $\geq 5$ years old may result in better asthma control, less hospitalization, and less use of relief medication prescription. ${ }^{70}$

1.4 Dry-Powder Inhaler. A DPI is a breath-actuated device that requires sufficient inspiratory flow to inhale the medication from the device. The patient's inspiratory flow disperses the dry particles and draws them from the device into the lower airways. Patients unable to demonstrate sufficient inspiratory flow for the inhaler, particularly those in respiratory distress or children $<4$ years of age, may not reliably use DPIs. ${ }^{3,11,12,14,26,71,72}$ At 4 years of age and above, patients may be able to use the DPI if they are shown how to use it effectively and to generate sufficient inspiratory flow required by the device. ${ }^{73,74}$ Current DPIs are available in 3 categories: single-dose, multiple single-dose, and multiple-dose. Like the pMDI, and unlike nebulizers, the DPI is always provided as a drug/device combination. ${ }^{14}$

1.5 Interfaces Used with Aerosol Generators. Mouthpieces, masks, hoods, and spacers are the most common interfaces used between the aerosol generator and the patient. Evidence is lacking for better clinical response with one or another interface (eg, mask vs mouthpiece). Selection of interface is dependent on age, ability to use a mouthpiece, and patient preference. When a nebulizer is used, a mouthpiece is preferred, but a mask can be used if the patient cannot effectively hold the mouthpiece between the lips. Also, a face mask should be avoided in the delivery of corticosteroids, due to the side effects of steroid administration to the facial skin and eyes. A VHC is preferred when a pMDI is used in a patient with poor hand-breath coordination, and it can be used with a mask in patients unable to use a mouthpiece effectively. For a VHC with mask, a larger dead volume reduces aerosol delivery to infants. ${ }^{75,76}$ The lack of mask seal leads to a substantial decrease in aerosol delivery, ${ }^{21,75-78}$ and aerosolized medications delivered with a mask may inadvertently deposit in the eyes. ${ }^{23,24,76,79}$ Aerosolized drug delivery to children $<3$ years old should be through a mask or hood. For an infant, a hood is as efficient as a mask, its use results in better therapeutic index with minimal deposition at the infant's eyes, and it is preferred by parents for aerosol drug administration. ${ }^{80-83}$

\section{ADS 2.0 PATIENT PREPARATION}

2.1 Identify patient and assess the need for inhaled medication.

2.2 Describe the procedure to be performed, how it will be performed, what the patient is expected to do, and how frequently it will be performed.

2.3 Utilize age-appropriate strategies.

2.4 Clear the airways as needed.

2.5 Position the patient appropriately.

\section{ADS 3.0 PROCEDURE}

It is recommended that techniques for using aerosol delivery devices follow the procedural steps from A Guide to Aerosol Delivery Devices for Respiratory Therapists. ${ }^{14}$ In some cases, the FDA has approved a drug-device combination with specific nebulizers identified on the drug label. Table 2 shows approved nebulizers for specific drug formulations. ${ }^{14}$ The use of specified nebulizers is recommended. 
Table 2. Approved Devices for Specific Drug Formulations

\begin{tabular}{ll}
\hline \hline \multicolumn{1}{c}{ Drug Formulation } & \multicolumn{1}{c}{ Approved Aerosol Device } \\
\hline Bronchodilator & Nebulizer type not specified \\
Acetylcysteine & Nebulizer type not specified \\
Budesonide (Pulmicort & $\begin{array}{c}\text { Should not be used with ultrasonic } \\
\text { nebulizer }\end{array}$ \\
Tobpules) & Pari LC \\
Dornase alfa (Pulmozyme) & Hudson T Up-draft II, Marquest Acorn II, \\
& Pari LC, Durable Sidestream, Pari Baby \\
Pentamadine (NebuPent) & Marquest Respirgard II \\
Ribavirin (Virazole) & Small Particle Aerosol Generator (SPAG) \\
Iloprost (Ventavis) & I-neb Adaptive Aerosol Delivery (AAD) \\
& System \\
Aztreonam (Cayston) & Altera nebulizer system \\
Treprostinil (Tyvaso) & Tyvaso inhalation system \\
\hline
\end{tabular}

\section{ADS 4.0 FOLLOW-UP CARE}

4.1 Monitor the patient for adverse response.

4.2 Assess whether or not the patient is using the device correctly.

4.3 Assess response to therapy and document findings.

\section{ADS 5.0 SETTING}

Aerosolized medications can be administered by properly trained healthcare providers in a number of settings that include (but are not limited to):

5.1 Hospital

5.2 Extended care facility

5.3 Out-patient clinic

5.4 Physician's office

5.5 Transport vehicle

5.6 Home

\section{ADS 6.0 INDICATIONS}

\subsection{SVN}

6.1.1 Delivery of aerosolized medications available as a solution ${ }^{64,84,85}$

6.1.2 Need to modify drug concentration or combine compatible nebulized solutions ${ }^{14}$

6.1.3 Device of choice for patients who are unable to operate, coordinate, cooperate, or perform the necessary inspiratory maneuvers required for the use of other devices (eg, infants, small children, and the elderly)

6.2 SVN With Mouthpiece

6.2.1 Delivery of aerosolized medications to patients who are able to utilize a mouthpiece correctly ( $>3$ years of age $)^{2,3,8,9,14,84}$
6.2.2 Breath-actuated nebulizers are indicated in patients $\geq 5$ years if they are able to demonstrate their ability to open the valve.

6.3 SVN With Mask

6.3.1 Delivery of aerosolized medications to patients unable to utilize a mouthpiece $(\leq 3$ years of age) $)^{2,3,8,9,16,86}$

6.4 SVN With Hood

6.4.1 Delivery of aerosolized drugs to young children who cannot tolerate face mask ${ }^{80-82}$

6.5 LVN

6.5.1 Delivery of continuous aerosolized bronchodilator 62,87

6.6 pMDI: General Indications

6.6.1 Delivery of medications that are available in pMDI form ${ }^{86}$

6.6.2 Convenience of being small and portable

6.7 Breath-actuated pMDI

6.7.1 Delivery of inhaled bronchodilator for patients with poor hand-breath coordination who can use a mouthpiece

6.8 pMDI with VHC and mouthpiece

6.8.1 Patients who are able to hold the mouthpiece during treatment

6.9 pMDI with VHC and mask

6.9.1 Small children, elderly, and others unable to use a mouthpiece ${ }^{2,86}$

6.9.2 Reduces need for actuation and inspiratory maneuver coordination

6.9.3 Reduces oropharyngeal impaction, particularly with the delivery of corticosteroids ${ }^{88}$

6.10 pMDI with spacer (non-valved pMDI accessory device)

6.10.1 Patients who can coordinate inspiration and actuation

6.10.2 Reduces oropharyngeal impaction, particularly with the delivery of corticosteroids ${ }^{88}$

\subsection{DPI}

6.11.1 Delivery of aerosolized medications available as DPI ${ }^{89}$

6.11.2 Patients who are able to generate sufficient inspiratory flow for the specific inhaler ${ }^{35,36,90}$

\section{ADS 7.0 ASSESSMENT OF OUTCOME}

Appropriate selection of an aerosol generator is reflected by the following evidence:

7.1 A positive clinical outcome after aerosol therapy: 7.1.1 Desired medication effect is observed, as indicated by an improvement in subjective (eg, physical examination) and objective (eg, spirometry) assessments, in short time frame if bronchodilators are used, and over longer time frame for 
other drugs such as antibiotics or corticosteroids. ${ }^{91,92}$

7.2 Use of proper technique in applying aerosol delivery systems:

7.2.1 Healthcare providers must demonstrate competency with proper technique and patient instruction of aerosol delivery systems. ${ }^{15,93-96}$

7.2.2 Patients and family members must demonstrate proper technique with use of prescribed aerosol delivery systems. ${ }^{93-96}$

7.3 Patient adherence with application of aerosol delivery systems:

7.3.1 Patients and family members demonstrate adherence with the use of aerosol delivery systems with initiation of therapy and periodic follow-up visits. ${ }^{94-96}$

\section{ADS 8.0 CONTRAINDICATIONS}

8.1 No contraindications exist to the administration of aerosols by inhalation. Aerosol therapy is contraindicated when there is a known hypersensitivity or history of an allergic reaction to a specific pharmacologic agent, its preservatives, and/or its excipients. ${ }^{97}$ 8.2 Contraindications associated with specific medications being delivered may exist. Pharmaceutical information in the package insert should be consulted for relative contraindications.

8.3 Aerosol generators should not be used for patients with known allergies to medication preservatives and other excipients.

8.4 A pMDI or DPI should not be used for patients unable to perform the respiratory maneuver required to deliver the drug.

\section{ADS 9.0 HAZARDS/COMPLICATIONS}

\subsection{Aerosol Delivery}

9.1.1 When aerosol generators are contaminated with bacteria, they increase the risk of infection in patients with respiratory diseases. ${ }^{98-105}$

9.1.2 Care providers and bystanders have the risk of infection due to the inhalation of pathogens and second hand aerosols during aerosol therapy. ${ }^{106}$ If indicated, negative pressure rooms and personal protective equipment should be used. ${ }^{107-109}$

9.1.3 Workplace exposure to aerosol may increase the risk of asthma-like symptoms and cause occupational asthma. ${ }^{14,110-112}$

9.1.4 Malfunction of device and/or improper technique may result in underdosing or overdosing. ${ }^{41-43,96,113-116}$
9.1.5 Specific pharmacologic agents can produce adverse side effects such as headache, insomnia, tachycardia, tremor, and nervousness with adrenergic agents; local topical effects with anticholinergics; airway reactivity with antibiotics, hypertonic saline, inhaled corticosteroids, and bronchodilators; systemic/local effects with corticosteroids; and bad taste with mucolytics and hypertonic saline. ${ }^{14,117}$

9.1.6 Bronchospasm may be induced due to a cold and high-density aerosol administration in patients with pulmonary diseases. ${ }^{117-119}$

9.1.7 The prescription of aerosol delivery devices for use in the home can lead to misuse if the user has not been properly trained..$^{95,96,120}$

\subsection{SVN}

9.2.1 There may be an increase in the drug concentration in the nebulizer cup at the end of the treatment when jet and ultrasonic nebulizers are used. ${ }^{43,121-123}$

9.2.2 The nebulizer may become contaminated and can be a source of infection. ${ }^{124}$

9.3 LVN

9.3.1 There may be an increase in the drug concentration in the nebulizer cup when jet and ultrasonic nebulizers are used.

9.3.2 Side effects may occur at any time during continuous nebulization, and frequent assessment is required. $62,87,125$

9.3.3 The nebulizer may become contaminated and can be a source of infection.

9.3.4 Drug concentration increases over time, and the solution might need to be changed after 5 hours of operation..$^{58}$

9.4 pMDI

9.4.1 Inappropriate patient use may result in underdosing or overdosing. . $^{7,66,95,126}$

9.4.2 Reaction to propellants and other additives such as coughing and wheezing may occur. ${ }^{64,117,126}$

9.4.3 Oropharyngeal impaction of corticosteroid may result in local side effects such as candidiasis. ${ }^{64,126}$

9.4.4 Immersion of the canister in water may result in valve blockage. ${ }^{127}$

\subsection{DPI}

9.5.1 Airway irritation and dysphonia from dry powder may occur. ${ }^{64,126}$

9.5.2 Reaction to lactose or glucose carriers may occur. ${ }^{64}$

9.5.3 Oropharyngeal impaction of corticosteroid may result in local side effects. 


\section{ADS 10.0 LIMITATIONS OF METHOD}

\subsection{SVN}

10.1.1 Deposition of medication into the lungs ranges from $1-15 \%$ of the dose ${ }^{128-133}$ and may vary from brand to brand of SVN, and unit to unit of the same brand. ${ }^{65,115,128,134}$

10.1.1.1 Drug delivery varies with different nebulizer types..$^{42,65,115,134}$ If specified, only the nebulizer cited on the drug label should be used.

10.1.1.2 Examples of drugs that require approved nebulizers include budesonide, tobramycin, dornase alfa, pentamidine, iloprost, treprostinil, and aztreonam (see Table 2).

10.1.2 Patients with smaller tidal volumes and rapid respiratory rates, particularly neonates ${ }^{130,135}$ and dyspneic patients with shallow breathing, may inhale less of the aerosolized agent and receive less of the dose when nebulization is continuous. ${ }^{40,130}$

10.1.3 Patients with airways of smaller diameter may receive a smaller fraction of the total particles produced. ${ }^{10,130,136}$

10.1.4 Crying children receive virtually no aerosol drug to the lungs. ${ }^{137,138}$

10.1.4.1 Most of the inhaled dose deposits in the upper airways and is then swallowed.

10.1.4.2 Inhaled drugs should be given to infants when they are breathing quietly. ${ }^{139}$

10.1.5 Fill volume in the SVN affects output. ${ }^{134}$ Since filling volumes may be different, it is suggested to follow the drug label or device manufacturer's product insert to cover those devices that are not labeled for specific use with a particular medication.

10.1.6 Approximately $25-50 \%$ of the initial solution volume remains on the internal walls and reservoir of the jet nebulizer after aerosol therapy is completed. $41,43,129$

10.1.6.1 Concentration of the solution increases during nebulization, resulting in retention of much of the dose in the jet nebulizer. ${ }^{43,84,129}$

10.1.7 Aerosol is lost during the expiratory phase of breathing unless a breath-actuated design or a design with a reservoir bag is used. ${ }^{41,43,126}$

10.1.8 Duration of treatment is variable and may be prolonged. A prolonged treatment time may be associated with reduced patient adherence to prescribed therapy.

10.1.9 Use is labor-intensive and costly. ${ }^{140-142}$
10.1.10 The need for a power source makes the SVN less portable, particularly in the ambulatory setting, outside of the home. ${ }^{11,14,64,84}$

10.1.11 SVNs require preparation and cleaning. ${ }^{14,64}$

10.2 SVN and LVN With Face Mask

10.2.1 Cold, wet mist may be irritating to children and may limit the time that the treatment is tolerated. ${ }^{15,85}$

10.2.2 Aerosol deposition is reduced because of upper airway impaction. ${ }^{136}$

10.2.3 Use of LVN for bronchodilator delivery is limited to use in a critical care setting and not appropriate for home use.

10.2.4 Leak between the mask and the face decreases the amount of aerosol inhaled by the patient. ${ }^{17,18}$

10.3 pMDI

10.3.1 Patients who cannot perform hand-breath coordination or proper inhalation technique should not use a pMDI. $7,10,35,36,126,143,144$

10.3.2 Failure to shake a pMDI before each use can interfere with correct drug release.7,66,95,126,144

10.3.3 Failure to prime a pMDI can also affect correct drug release. $7,66,126$

10.3.4 Use of a pMDI without a spacer device results in greater oropharyngeal impaction and a reduction in airway deposition. ${ }^{64,84,126}$

10.3.5 Inadequate or inaccurate instruction and technique may result in misuse and reduced aerosol deposition. ${ }^{10,85,126}$

10.3.6 Propellants, excipients, and drugs may cause bronchospasm in some patients with hyperreactive airway diseases.

10.3.6.1 The breath-actuated pMDI (Autohaler) uses chlorofluorocarbon (CFC) as a propellant.

10.3.7 Average aerosol deposition in the lungs ranges from $1 \%$ to $40 \%$ of the total dose, depending on size, age, device and interface. ${ }^{4,67,68,145-147}$

10.3.8 Lack of Built-In Dose Counter.

10.3.8.1 Dose counters are available for some brands, but add to the cost of the pMDI alone. $6,7,14$

\subsection{DPI}

10.4.1 The efficiency of DPI is dependent upon patient's inspiratory flow. In clinical situations where inspiratory flow is $<40-60 \mathrm{~L} / \mathrm{min}$, such as respiratory disease exacerbations or children $<4$ years old, ${ }^{72,85}$ use of DPI is associated with reduced lung deposition. ${ }^{64,72,130}$

10.4.2 Vulnerable to ambient humidity or exhaled humidity. ${ }^{10,64,84,85}$ 
10.4.3 High oropharyngeal impaction. ${ }^{85,130}$

10.4.3.1 Average deposition in the lungs is $10-25 \%$ of the total dose. ${ }^{84,85}$

10.4.4 If a single-dose DPI is used, additional time is needed to load the dose, and the patient must be capable of loading the dose before using the DPI.

10.4.5 Patients are less aware of delivered dose unless the DPI has a built-in dose counter.

10.4.6 Limited range of drugs. ${ }^{7,90,126}$

10.4.7 Wide range of designs with different ways to load the dose may lead to incorrect use. This can be best resolved by proper patient and caregiver education and return demonstration.

10.5 Device Interface

10.5.1 Face Mask

10.5.1.1 Face masks with larger dead space volume reduce aerosol delivery to infants and children. ${ }^{75,148}$

10.5.1.2 Leaks between the mask and the face decrease the amount of aerosol inhaled by the patient. $18,22,23,75,77,78,149-154$

10.5.1.2.1 In infants and small children, a small leak decreases drug inhaled by $>50 \%$.

10.5.1.3 Aerosolized medications delivered with a face mask may inadvertently deposit in the eyes, resulting in eye irritation. $23,76,79$

10.5.2 Blow-by. Blow-by significantly decreases aerosol delivery as the distance from the device and the patient's face is increased. It is ineffective and should be discouraged. ${ }^{133,155,156}$

10.5.3 Mouthpiece

10.5.3.1 Inappropriate patient use may result in underdosing.

10.5.4 Spacer/VHC

10.5.4.1 Using the spacer/VHC with the pMDI increases cost.

10.5.4.2 Assembly is necessary.

10.5.4.3 All spacers do not eliminate coordination problems.

10.5.4.3.1 Open tube spacer/accessory devices (non-valved) require coordination.

10.5.4.3.2 A spacer/accessory device with one-way valve (ie, VHC) eliminates coordination problems.

10.5.4.4 Dose delivery can be affected in some spacer designs if the device does not fit the pMDI properly. $6,14,126$

10.5.4.5 Electrostatic charge decreases aerosol delivery. ${ }^{148}$

10.5.4.6 The spacer/VHC is larger and more cumbersome than the pMDI alone. ${ }^{10,126}$
10.5.4.6.1 VHCs with large volume are disadvantageous for infants and small children, as it is difficult to empty larger VHCs with fewer inhalations. ${ }^{148}$

10.5.4.7 All spacer/VHCs may not fit all pMDIs.

10.5.4.8 Improper use of VHC results in inconsistent aerosol delivery. ${ }^{148}$

10.5.4.9 Possible contamination with inadequate cleaning.

10.5.4.10 Valve malfunction in the VHC may decrease drug delivery.

10.5.4.11 The inspiratory flow and the number of inhalations required by children $<3$ years to effectively use VHC with mask is not completely understood. ${ }^{2,10,85,135}$

10.6 Drug pharmacokinetics and pharmacodynamics are markedly altered in neonates and may require dose adjustments. ${ }^{15,93,130,147}$

\section{ADS 11.0 RESOURCES}

\subsection{Equipment}

11.1.1 Power source such as electricity, hospital compressed oxygen or air, portable oxygen or air cylinder, or domiciliary air compressor capable of producing a flow of $6-8 \mathrm{~L} / \mathrm{min} .{ }^{64,84}$

11.1.2 Aerosol Generators

11.1.2.1 SVN capable of producing a high drug output, short nebulization time, aerosol particles with a mass median aerodynamic diameter (MMAD) of 1-5 $\mu \mathrm{m}$, and with a low residual volume. ${ }^{11,12,41,129,157}$ Characteristics of nebulizers may vary among brands, and among units of the same brand. ${ }^{115,128,134,158}$

11.1.2.2 LVN capable of producing aerosol particles with an MMAD of 1-5 $\mu \mathrm{m}$, with face mask

11.1.2.3 pMDI, which includes the medication canister and actuator, with appropriate accessories for the patient's ability and circumstances

11.1.2.4 DPI with accompanying medication capsule/blister and dispenser

11.1.3 Interface

11.1.3.1 Face mask for small children unable to utilize a mouthpiece. ${ }^{2,16,86}$

11.1.3.2 Mouthpiece, with or without extension reservoir, depending on the type of nebulizer used. ${ }^{84}$

11.1.3.3 VHC or spacer with mouthpiece or mask, depending on the patient's age and physical and cognitive ability ${ }^{5}$ 
Table 3. Approximate Costs of Nebulizers in 2011

\begin{tabular}{lc}
\hline \hline \multicolumn{1}{c}{ Aerosol Generator } & $\begin{array}{c}\text { United States } \\
\text { Dollars }\end{array}$ \\
\hline Jet nebulizer with reservoir & $1-3$ \\
Jet nebulizer with collection bag & $4-5$ \\
Breath-enhanced nebulizer & $4-20$ \\
Breath-actuated nebulizer & $4-6$ \\
Ultrasonic nebulizer medication chamber & $1-5$ \\
Ultrasonic handset replacement & $100-250$ \\
Vibrating mesh nebulizer & $40-150$ \\
\hline
\end{tabular}

11.1.3.4 Hood, depending on the patient's age and tolerance as well as parents' preference $^{81-83}$

11.1.4 Medication and Diluent

11.1.4.1 Selection of an aerosol generator is limited by drug availability for a specific device or type of aerosol generator.

11.1.5 Cost

11.1.5.1 Selecting the least expensive aerosol generator for the patient is essential. The cost of an aerosol generator depends upon the type of aerosol device, its brand, drug formulation, and dosage. While jet nebulizers are low-cost, newer and more efficient aerosol generators are more expensive. ${ }^{14} \mathrm{Ta}-$ ble 3 shows the cost of nebulizers.

11.1.5.2 Since aerosol treatment with pMDI reduces the treatment time at the bedside and increases the productivity of respiratory therapists, it is considered an economical alternative to nebulizer for aerosol delivery to patients with pulmonary diseases. ${ }^{140,141,159-164}$ Previous studies reported success in substituting a pMDI for a nebulizer by documenting a 30-50\% reduction in the annual cost of aerosol therapy. ${ }^{140,142,165,166}$ However, success in this substitution depends on proper planning, careful implementation, and comprehensive education programs that were directed to physicians, respiratory therapists, and other healthcare professionals. Also, it must be noted that some medications are not available in the form of pMDI, and some patients are not capable of using pMDI correctly, due to their age and physical and cognitive abilities.

11.2 Most healthcare providers do not know how to use aerosol generators correctly. ${ }^{167-171}$ Healthcare providers responsible for delivery of aerosolized medications should have demonstrated and documented knowledge and skills related to:
11.2.1.1 Aerosol delivery devices and their limitations ${ }^{94,95,114}$

11.2.1.2 Assembly, care, and use of aerosol delivery devices $94,95,114$

11.2.1.3 Provision of comprehensive patient and lay caregiver instruction $86,172,173$

11.2.1.4 Medications being delivered, including contraindications, potential side effects, and desired response

11.2.1.5 Incompatibility of drugs if combined in the nebulizer cup ${ }^{174-176}$

11.2.1.6 Recognition and response to adverse reactions during medication delivery, and modification of treatment accordingly 11.2.1.7 Performance of the necessary subjective and objective assessments in order to determine medication efficacy and the patient's ability to properly utilize aerosol delivery devices ${ }^{94,95,177}$

11.2.2 Healthcare providers should train and retrain patients about how to use aerosol generators correctly. $94,95,178$

11.2.3 Most patients do not use their inhalers well enough to benefit from their prescribed medication. ${ }^{120,179-181}$ Patients and/or family members or lay caregivers should:

11.2.3.1 Demonstrate proper use and understanding of the aerosol delivery device and delivery technique. $94,95,113,173,177,182-184$

11.2.3.2 Demonstrate proper assembly, cleaning, and care of the aerosol delivery device, and aseptic medication preparation. ${ }^{95,113}$

11.2.3.3 Demonstrate an understanding of medication purpose, dosage, indications, and side effects, be able to alter medication as needed, and know when to report to physician or surrogate. ${ }^{95}$

\section{ADS 12.0 MONITORING}

12.1 Observe delivery technique of spontaneously breathing patients who are able to self-administer aerosolized medications.

12.1.1 A periodic slow deep inhalation with an inspiratory pause/hold is performed during SVN treatments. ${ }^{157}$ Hyperventilation should be avoided, and the patient should be observed to ensure that aerosol mist is being inhaled.

12.1.2 pMDI actuation occurs at the beginning of inhalation, followed by a slow inspiration and breath-hold for up to 10 seconds. ${ }^{157}$

12.1.3 Patient is able to produce a rapid inhalation in order to fully activate and discharge DPI. 
12.2 Observe patient and/or patient's family member following instructions and demonstration. ${ }^{94,95}$

12.2.1 Proper understanding and return-demonstration of delivery device and accompanying equipment is observed.

12.2.2 Proper understanding and preparation of medication is observed.

12.3 Observe response to medication by performing subjective (eg, physical examination) and objective (eg, pulmonary function measurements) assessments and other diagnostic techniques that are appropriate for the specific medication being delivered.

12.3.1 Ensure that medication volume is nebulized over desired amount of time when using LVN.

12.4 Documentation

12.4.1 Successful training of patients and/or patient's family member is documented in the patient's medical record. ${ }^{95}$

12.4.2 Treatments administered in a clinical setting are documented in the patient's medical record. Information on medication dose, frequency, response, and adverse reactions are included.

\section{ADS 13.0 FREQUENCY}

Aerosol delivery devices are used according to the frequency of the prescribed medication.

\section{ADS 14.0 INFECTION CONTROL}

14.1 Standard precautions and measures to limit the transmission of airborne pathogens must be adhered to at all times. ${ }^{103,124}$

\subsection{SVN}

14.2.1 Jet nebulizers are for single patient use and should be changed every 24 hours, or at a frequency determined in collaboration with infection control, based on local data, when used in the hospital. $37,124,185-187$

14.2.2 Jet nebulizers should be cleaned, rinsed with sterile water, and air-dried between treatments on the same patient. ${ }^{14,124,186}$

14.2.3 At home, parts of aerosol generators should be washed with soap and hot water after each treatment, with care not to damage any parts of the aerosol generator. ${ }^{103}$

14.2.4 Mesh and ultrasonic nebulizers should be cleaned and disinfected based on the manufacturer's recommendations. The mesh should not be touched during the cleaning of mesh nebulizers, in order to prevent the damage of the unit. ${ }^{14}$

14.3 LVN

14.3.1 LVNs are for single patient use.

\section{4 pMDI}

14.4.1 The plastic boot of pMDIs should be cleaned according to the manufacturer recommendation.

14.4.2 When a spacer is used with a pMDI, it should be cleaned before first use, and then periodically cleaned based on the manufacturer's suggestions.

\subsection{DPI}

14.5.1 DPI and accessories are for single patient use only. Clean or replace when they appear dirty. 14.5.2 DPIs should not be submerged in water. Also, they should be kept dry, as moisture will decrease drug delivery. ${ }^{14}$

14.5.3 Although there is no clear evidence about the cleaning practice for DPI, each manufacturer has recommendations for periodic cleaning and suggests wiping the mouthpiece of the DPI with a clean dry cloth. ${ }^{14}$

14.6 Aerosol Solutions

14.6.1 Use only sterile fluids, and dispense them aseptically. ${ }^{124}$

14.6.2 Unit dose medications are recommended, when possible. ${ }^{102,124}$

14.6.2.1 Multi-dose drug containers have been associated with contaminated nebulizers and are a potential source of spreading nosocomial infections. ${ }^{100-102,188}$

14.6.3 If medications from multidose vials have to be used, they should be handled, dispensed, and stored according to manufacturer's instructions.

14.7 Patients should be instructed to rinse the mouth with water following each administration of inhaled steroids.

\section{ADS 15.0 RECOMMENDATIONS}

The recommendations below are made following the Grading of Recommendations Assessment, Development, and Evaluation (GRADE) ${ }^{189,190}$ criteria.

15.1 It is recommended that selection of the appropriate aerosol generator and interface be made based on the patient's age, physical and cognitive ability, cost, and the availability of the prescribed drug for use with a specific device. (1B)

15.2 Nebulizers and pMDIs with VHCs are suggested for use with children $\leq 4$ years of age and adults who cannot coordinate the use of pMDI or DPI. (2B)

15.3 It is suggested that administration of aerosols with DPIs be restricted to patients $\geq 4$ years of age who can demonstrate sufficient flow for the specific inhaler. (2B) 
15.4 For patients who cannot correctly use a mouthpiece, aerosol masks are suggested as the interface of choice. (2B)

15.5 It is suggested that blow-by not be used for aerosol administration. (2B)

15.6 It is suggested that aerosol therapy be administered with a relaxed and nondistressed breathing pattern. (2B)

15.7 Unit dose medications are suggested to reduce the risk of infection. (2C)

15.8 It is suggested that nebulizer/drug combinations should be used as approved by the FDA. (2A)

15.9 It is recommended that healthcare providers know the correct use of aerosol generators; they should teach and periodically re-teach patients about how to use aerosol devices correctly. (1A)

15.10 It is suggested that intermittent positive-pressure breathing should not be used for aerosol therapy. (2B)

15.11 It is recommended that either nebulizer or pMDI can be used for aerosol delivery during NIV. (1B)

\subsection{ADS CPG IDENTIFYING INFORMATION}

\subsection{Adaptation}

Original Publication: Respir Care 1995;40(12):13251335

16.2 Guideline Developers

American Association for Respiratory Care Clinical Practice Guidelines Steering Committee.

Arzu Ari PhD RRT PT CPFT FAARC (Member), Division of Respiratory Therapy, Georgia State University, Atlanta, Georgia.

Ruben D Restrepo MD RRT FAARC (Chair), The University of Texas Health Sciences Center at San Antonio, San Antonio, Texas.

16.3 Source(s) of Funding

None

16.4 Financial Disclosures/Conflicts of Interest The authors have disclosed no conflicts of interest.

\section{REFERENCES}

1. Welch MJ. Nebulization therapy for asthma: a practical guide for the busy pediatrician. Clin Pediatr 2008;47(8):744-756.

2. Everard ML. Guidelines for devices and choices. J Aerosol Med 2001;14(Suppl 1):S59-S64.

3. National Asthma Education and Prevention Program. Expert panel report 3 (EPR-3): guidelines for the diagnosis and management of asthma-summary report 2007. J Allergy Clin Immunol 2007;120(5 Suppl):S94-S138. Erratum in: J Allergy Clin Immunol 2008;121(6): 1330.

4. Devadason SG, Le Souef PN. Age-associated factors influencing the efficacy of various forms of aerosol therapy. J Aerosol Med 2002;15(3):343-345.
5. Pongracic JA. Asthma delivery devices: age-appropriate use. Pediatr Ann 2003;32(1):50-54.

6. Hess DR. Aerosol delivery devices in the treatment of asthma. Respir Care 2008;53(6):699-723.

7. Rau JL. Practical problems with aerosol therapy in COPD. Respir Care 2006;51(2):158-172.

8. Everard ML. Aerosol delivery to children. Pediatr Ann 2006;35(9): 630-636.

9. Everard ML. Inhalation therapy for infants. Adv Drug Deliv Rev 2003;55(7):869-878.

10. Everard ML. Inhaler devices in infants and children: challenges and solutions. J Aerosol Med 2004;17(2):186-195.

11. Cole C. Special problems in aerosol delivery: neonatal and pediatric considerations. Respir Care 2000;45(6):646-651.

12. Brand P. Key issues in inhalation therapy in children. Curr Med Res Opin 2005;50(10):1313-1321.

13. Ahrens RC. The role of the MDI and DPI in pediatric patients: "children are not just miniature adults". Respir Care 2005;50(10): 1323-1328.

14. Ari A, Hess D, Myers TR, Rau JL. A guide to aerosol delivery devices for respiratory therapists 2nd ed. Irving, TX: American Association for Respiratory Care; 2009.

15. Rubin B, Fink J. Aerosol therapy for children. Respir Care Clin N Am 2001;7(2):100-108.

16. Lowenthal D, Kattan M. Facemasks versus mouthpieces for aerosol treatment of asthmatic children. Pediatr Pulmonol 1992;14(3):192196.

17. Erzinger S, Schueepp KG, Brooks-Wildhaber J, Devadason SG, Wildhaber JH. Facemasks and aerosol delivery in vivo. J Aerosol Med 2007;20(Suppl 1):S78-S83.

18. Nikander K, Berg E, Smaldone GC. Jet nebulizers versus pressurized metered dose inhalers with valved holding chambers: effects of the facemask on aerosol delivery. J Aerosol Med 2007;20(Suppl 1):S46-S55.

19. Lin HL, Restrepo RD, Gardenhire DS, Rau JL. Effect of face mask design on inhaled mass of nebulized albuterol, using a pediatric breathing model. Respir Care 2007;52(8):1021-1026.

20. Smaldone GC, Sangwan S, Shah A. Facemask design, facial deposition, and delivered dose of nebulized aerosols. J Aerosol Med 2007;20(Suppl 1):S66-S75.

21. Amirav I, Newhouse MT. Review of optimal characteristics of face-masks for valved-holding chambers (VHCs). Pediatr Pulmonol 2008;43(3):268-274.

22. Amirav I, Newhouse MT. Aerosol therapy with valved holding chambers in young children: importance of the facemask seal. Pediatrics 2001;108(2):389-394.

23. Smaldone GC, Berg E, Nikander K. Variation in pediatric aerosol delivery: importance of facemask. J Aerosol Med 2005;18(3):354363.

24. Sangwan S, Gurses BK, Smaldone GC. Facemasks and facial deposition of aerosols. Pediatr Pulmonol 2004;37(5):447-452.

25. Dolovich MB, Ahrens RC, Hess DR, Anderson P, Dhand R, Rau JL, et al; American College of Chest Physicians; American College of Asthma, Allergy, and Immunology. Device selection and outcomes of aerosol therapy: evidence-based guidelines. Chest 2005; 127(1):335-371.

26. Geller DE. Comparing clinical features of the nebulizer, metereddose inhaler, and dry powder inhaler. Respir Care 2005;50(10): 1313-1321.

27. Cates CJ, Rowe BH, Bara A. Holding chambers versus nebulisers for beta-agonist treatment of acute asthma. Cochrane Database Syst Rev 2002(2):CD000052. 
28. Parkin P, Saunders N, Diamond S, Winders P, Macarthur C. Randomized trial spacer vs nebulizer for acute asthma. Arch Dis Child 1995;72(3):239-240.

29. Kerem E, Levison H, Schuh S, O’Brodovich H, Reisman J, Bentur L, Canny GJ. Efficacy of albuterol administered by nebulizer versus spacer device in children with acute asthma. J Pediatr 1993; 123(2):313-317.

30. Deerojanawong J, Manuvakorn W, Prapphal N, Harnruthakorn C, Sritippavawan S, Samransamruaikit R. Randomized controlled trial of salbutamol aerosol therapy via metered dose inhaler-spacer vs jet nebulizer in young children with wheezing. Pediatr Pulmonol 2005; 39(5):466-472.

31. Ploin D, Chapuis FR, Stamm D, Robert J, David L, Chatelain PG, et al. High-dose albuterol by metered-dose inhaler plus a spacer device versus nebulization in preschool children with recurrent wheezing: a double-blind, randomized equivalence trial. Pediatrics 2000;106(2 Pt 1):311-317.

32. Vilarinho LC, Cardeal Mendes CM, de Freitas Souza LS. Metereddose inhalers with home-made spacers versus nebulizers to treat moderate wheezing attacks in children. J Pediatr (Rio J) 2003; 79(5):403-412.

33. Delgado A, Chou KJ, Silver EJ, Crain EF. Nebulizers vs metereddose inhalers with spacers for bronchodilator therapy to treat wheezing in children aged 2 to 24 months in a pediatric emergency department. Arch Pediatr Adolesc Med 2003;157(1):76-80.

34. Bacharier LB, Boner A, Carlsen KH, Eigenmann PA, Frischer T, Götz M, et al; European Pediatric Asthma Group. Diagnosis and treatment of asthma in childhood: a PRACTALL consensus report. Allergy 2008;63(1):5-34. Erratum in: Allergy 2008;63(5):630.

35. Voshaar T, App E, Berdel D, Buhl R, Fischer J, Gessler T, et al; Arbeitsgruppe Aerosolmedizin der Deutschen Gessellschaft für Pneumologie. [Recommendations for the choice of inhalatory systems for drug prescription]. Pneumologie 2001;55(12):579-586. Article in German.

36. Chapman K, Voshaar T, Virchow JC. Inhaler choice in primary practice. Eur Respir Rev 2005;14(96):117-122.

37. Boe J, Dennis JH, O'Driscoll BR, Bauer TT, Carone M, Dautzenberg B, et al; European Respiratory Society Task Force On the Use of Nebulizers. European Respiratory Society guidelines on the use of nebulizers. Eur Respir J 2001;18(1):228-242.

38. Dolovich MB, Dhand R. Aerosol drug delivery: developments in device design and clinical use. Lancet 2010;377(9770):1032-1045.

39. Ari A, Fink JB. Guidelines to aerosol devices in infants, children and adults: which to choose, why and how to achieve effective aerosol therapy? Expert Rev Respir Med 2011;5(4):561-572.

40. Everard ML, Clark AR, Milner AD. Drug delivery from jet nebulisers. Arch Dis Child 1992;67(5):586-591.

41. Rau JL. Design principles of liquid nebulization devices currently in use. Respir Care 2002;47(11):1257-1275.

42. Le Brun PP, de Boer AH, Heijerman HG, Frijlink HW. A review of the technical aspects of drug nebulization. Pharm World Sci 2000; 22(3):75-81.

43. Hess DR. Nebulizers: principles and performance. Respir Care 2000; 45(6):609-622.

44. Kurosaka F, Nishio H. Comparison of the bronchodilative effects of salbutamol delivered via three mesh nebulizers in children with bronchial asthma. Allergol Int 2009;58(4):529-535.

45. Dhand R. Aerosol delivery during mechanical ventilation: from basic techniques to new devices. J Aerosol Med Pulm Drug Deliv 2008;21(1):45-60.

46. Dhand R. Nebulizers that use a vibrating mesh or plate with multiple apertures to generate aerosol. Respir Care 2002;47(12):14061416.
47. Dolovich MB, Killian D, Wolff RK, Obminski G, Newhouse MT. Pulmonary aerosol deposition in chronic bronchitis: intermittent positive pressure breathing versus quiet breathing. Am Rev Respir Dis $1977 ; 115(3): 397-402$.

48. Hess DR. The mask for noninvasive ventilation: principles of design and effects on aerosol delivery. J Aerosol Med 2007;20(Suppl 1):S85-S98.

49. Pollack C, Fleisch K, Dowsey K. Treatment of acute bronchospasm with $\beta$-adrenergic agonist aerosols delivered by a nasal bilevel positive airway pressure circuit. Ann Emerg Med 1995;26(5):552557.

50. Nava S, Karakurt S, Rampulla C, Braschi A, Fanfulla F. Salbutamol delivery during non-invasive mechanical ventilation in patients with chronic obstructive pulmonary disease: a randomized, controlled study. Intensive Care Med 2001;27(10):1627-1635.

51. Brandao DC, Lima VM, Filho VG, Silva TS, Campos TF, Dean E, de Andrade AD. Reversal of bronchial obstruction with bi-level positive airway pressure and nebulization in patients with acute asthma. J Asthma 2009;46(4):356-361.

52. Fauroux B, Itti E, Pigeot J, Isabey D, Meignan M, Ferry G, et al. Optimization of aerosol deposition by pressure support in children with cystic fibrosis: an experimental and clinical study. Am J Respir Crit Care Med 2000;162(6):2265-2271.

53. Chatmongkolchart S, Schettino G, Dillman C, Kacmarek R, Hess D. In vitro evaluation of aerosol bronchodilator delivery during noninvasive positive pressure ventilation: effect of ventilator settings and nebulizer position. Crit Care Med 2002;30(11):2515-2519.

54. Branconnier M, Hess D. Albuterol delivery during noninvasive ventilation. Respir Care 2005;50(12):1649-1653.

55. Abdelrahim ME, Plant $P$, Chrystyn H. In-vitro characterisation of the nebulised dose during non-invasive ventilation. J Pharm Pharmacol 2010;62(8):966-972.

56. Reychler G. Comparison of lung deposition in two types of nebulization: intrapulmonary percussive ventilation vs jet nebulization. Chest 2004;125:502.

57. Reychler G, Wallemacq P, Rodenstein DO, Cumps J, Leal T, Liistro G. Comparison of lung deposition of amikacin by intrapulmonary percussive ventilation and jet nebulization by urinary monitoring. J Aerosol Med 2006;19(2):199-207.

58. Berlinski A, Willis JR, Leisenring T. In-vitro comparison of 4 large-volume nebulizers in 8 hours of continuous nebulization. Respir Care 2010;55(12):1671-1679.

59. Kelly H, Keim K, McWilliams B. Comparison of two methods of delivering continuously nebulized albuterol. Ann Pharmacotherapy 2003;37(1):23-26.

60. Papo MC, Frank J, Thompson AE. A prospective, randomized study of continuous versus intermittent nebulized albuterol for severe status asthmaticus in children. Crit Care Med 1993;21(10):14791486.

61. Khine H, Fuchs SM, Saville AL. Continuous vs intermittent nebulized albuterol for emergency management of asthma. Acad Emerg Med 1996;3(11):1019-1024.

62. Camargo CA Jr, Spooner CH, Rowe BH. Continuous versus intermittent beta-agonists in the treatment of acute asthma. Cochrane Database Syst Rev 2003(4):CD001115.

63. McPeck M, Tandon R, Hughes K, Smaldone GC. Aerosol delivery during continuous nebulization. Chest 1997;111(5):1200-1205.

64. Newman S. Aerosol generators and delivery systems. Respir Care 1991;36(9):939-951.

65. Yilmaz O, Sogut A, Kose U, Sakinci O, Yuksel H. Influence of ambulatory inhaled treatment with different devices on the duration of acute asthma findings in children. J Asthma 2009;46(2):191-193.

66. Rubin BK, Fink JB. Optimizing aerosol delivery by pressurized metered-dose inhalers. Respir Care 2005;50(9):1191-1200. 
67. Wildhaber JH, Janssens HM, Pierart F, Dore ND, Devadason SG, LeSouëf PN. High-percentage lung delivery in children from detergent-treated spacers. Pediatr Pulmonol 2000;29(5):389-393.

68. Wildhaber JH, Devadason SG, Hayden MJ, James R, Dufty AP, Fox RA, et al. Electrostatic charge on a plastic spacer device influences the delivery of salbutamol Eur Respir J 1996;9(19):19431946.

69. Wildhaber JH, Devadason SG, Eber E, Hayden MJ, Everard ML, Summers QA, LeSouëf PN. Effect of electrostatic charge, flow, delay and multiple actuations on the in vitro delivery of salbutamol from different small volume spacers for infants. Thorax 1996;51(10): 985-988.

70. Price D, Thomas M, Mitchell G, Niziol C, Featherstone R. Improvement of asthma control with a breath-actuated pressurised metered dose inhaler (BAI): a prescribing claims study of 5556 patients using a traditional pressurised metered dose inhaler (MDI) or a breath actuated device. Respir Med 2003;97(1):12-19.

71. Berger WE, Leflein JG, Geller DE, Parasuraman B, Miller CJ, O'Brien CD, O'Dowd L. The safety and clinical benefit of budesonide/formoterol pressurized metered-dose inhaler versus budesonide alone in children. Allergy Asthma Proc 2010;31(1):26-39.

72. Pedersen S, Hansen O, Fuglsang G. Influence of inspiratory flow rate upon the effect of a Turbuhaler. Arch Dis Child 1990;65(3): 308-310.

73. Amirav I, Newhouse MT. To inhale or not to inhale: is that the question? A simple method of DPI instruction. J Pediatr 2010; 156(2):339-339, e331.

74. Amirav I, Newhouse MT, Mansour Y. Measurement of peak inspiratory flow with in-check dial device to simulate low-resistance (Diskus) and high-resistance (Turbohaler) dry powder inhalers in children with asthma. Pediatr Pulmonol 2005;39(5):447-451.

75. Chavez A, McCracken A, Berlinski AB. Effect of face mask dead volume, respiratory rate and tidal volume on inhaled albuterol delivery. Pediatr Pulmonol 2010;45(3):224-229.

76. Smaldone GC. Assessing new technologies: patient-device interactions and deposition. Respir Care 2005;50(9):1151-1160.

77. Janssens HM, Tiddens HA. Facemasks and aerosol delivery by metered dose inhaler-valved holding chamber in young children: a tight seal makes the difference. J Aerosol Med 2007;20(Suppl 1): S59-S63.

78. Esposito-Festen J, Ates B, van Vliet F, Hop W, Tiddens H. Aerosol delivery to young children by pMDI-spacer: is facemask design important? Pediatr Allergy Immunol 2005;16(4):348-353.

79. Geller DE. Clinical side effects during aerosol therapy: cutaneous and ocular effects. J Aerosol Med 2007;20(Suppl 1):S100-S109.

80. Amirav I, Shakked T, Broday DM, Katoshevski D. Numerical investigation of aerosol deposition at the eyes when using a hood inhaler for infants-a 3D simulation. J Aerosol Med Pulm Drug Deliv 2008;(2):207-214.

81. Kugelman A, Amirav I, Mor F, Riskin A, Bader D. Hood versus mask nebulization in infants with evolving bronchopulmonary dysplasia in the neonatal intensive care unit. J Perinatol 2006;26(1): 31-36.

82. Amirav I, Balanov I, Gorenberg M, Groshar D, Luder AS. Nebuliser hood compared to mask in wheezy infants: aerosol therapy without tears! Arch Dis Child 2003;88(8):719-723.

83. Amirav I, Oron A, Tal G, Cesar K, Ballin A, Houri S, et al. Aerosol delivery in respiratory syncytial virus bronchiolitis: hood or face mask? J Pediatr 2005;147(5):627-631.

84. Kacmarek RM, Hess DR. The interface between patient and aerosol generator. Respir Care 1991;36(9):952-976.

85. Rau JL. Delivery of aerosolized drugs to neonatal and pediatric patients. Respir Care 1991;36(6):514-542.
86. Pedersen S. Choice of inhalation therapy in pediatrics. Eur Respir Rev 1994;4:85-88.

87. Scalabrin D, Naspitz C. Efficacy and side effects of salbutamol in acute asthma in children: comparison of the oral route and two different nebulizer systems. J Asthma 1993;30(1):51-59.

88. Canny G, Levison H. Childhood asthma: a rational approach to treatment. Ann Allergy 1990;64(5):406-418.

89. LaForce C, Ellis E, Kordansky D, Cocchetto D, Sharp J. Use and acceptance of Ventolin Rotacaps and the Rotohaler in 1235 asthmatic patients. Clin Therapeutics 1993;15(2):321-329.

90. Atkins PJ. Dry powder inhalers: an overview. Respir Care 2005; 50(10):1304-1312.

91. Lyttle B, Hollestelle A. Asthma: assessment and management in a pediatric hospital Can Fam Physician 1993;39:793-798.

92. Spier S, Drblik S, Lamarre A, Lapierre G, Marcotte J, Bourgeois M. A protocol for aerosol therapy in acute hospitalized asthmatics. J Asthma 1992;29(6):401-405.

93. Rubin BK, Fink JB. The delivery of inhaled medication to the young children. Pediatr Clin North Am 2003;50(3):717-731.

94. Fink JB. Inhalers in asthma management: is demonstration the key to compliance? Respir Care 2005;50(5):598-600.

95. Fink JB, Rubin BK. Problems with inhaler use: a call for improved clinician and patient education. Respir Care 2005;50(10):1360-1374.

96. Bendefy I. Home nebulisers in childhood asthma: survey of hospital supervised use. BMJ 1991;302(6786):1180-1181.

97. Flume PA, Mogayzel PJ Jr, Robinson KA, Rosenblatt RL, Quittell L, Marshall BC. Cystic fibrosis pulmonary guidelines: pulmonary complications: hemoptysis and pneumothorax. Am J Respir Crit Care Med 2010;182(3):298-306.

98. Wexler M, Rhame F, Blumental M, Cameron S, June B, Fish L. Transmission of gram-negative bacilli to asthmatic children via home nebulizers. Ann Allergy 1991;66(3):267-271.

99. Vassal S, Taamma R, Marty N, Sardet A, d'Athis P, Brémont F, et al. Microbiologic contamination study of nebulizers after aerosol therapy in patients with cystic fibrosis. Am J Infect Control 2000; 28(5):347-351.

100. Estivariz C, Bhatti L, Pati R, Jensen B, Arduino MJ, Jernigan D, et al. An outbreak of Burkholderia cepacia associated with contamination of albuterol and nasal spray. Chest 2006;130(5):1346-1353.

101. Hamill R, Georghiou P, Koza M, Goepfert P, Zenon G. Respiratory tract colonization and infection associated with nebulized albuterol therapy. Ann Intern Med 1995;122(10):762-766.

102. Rau JL, Restrepo RD. Nebulized bronchodilator formulations: unitdose or multi-dose? Respir Care 2003;48(10):926-939.

103. Lemming C, Marciel J, O'Malley C, Hazle L; Cystic Fibrosis Foundation. Stopping the spread of germs. http://www.cff.org/Uploaded Files/LivingWithCF/StayingHealthy/Germs/StoppingTheSpread/ Stopping-the-Spread-of-Germs.pdf. Accessed February 1, 2012.

104. Rosenfeld M, Emerson J, Astley S, Joy P, Williams-Warren J, Standaert TA, et al. Home nebulizer use among patients with cystic fibrosis. J Pediatr 1998;132(1):125-131.

105. Hutchinson G, Parker S, Pryor J, Duncan-Skingle F, Hoffman P, Hodson M. Home-use nebulizers: a potential primary source of Burkholderia cepacia and other colistin-resistant, gram-negative bacteria in patients with cystic fibrosis. J Clin Microbiol 1996; 34(3):584-587.

106. Segal-Maurer S, Kalkut G. Environmental control of tuberculosis: continuing controversy. Clin Infect Dis 1994;19(2):299-308.

107. Hui DS, Chow BK, Chu LC, Ng SS, Hall SD, Gin T, Chan MT. Exhaled air and aerosolized droplet dispersion during application of a jet nebulizer. Chest 2009;135(3):648-654.

108. Simonds A, Hanak A, Chatwin M, Morrell M, Hall A, Parker K. Evaluation of droplet dispersion during non-invasive ventilation, oxygen therapy, nebulizer treatment and chest physiotherapy in 


\section{AarC CPG: Aerosol Delivery Device Selection for Spontaneously Breathing Patients: 2012}

clinical practice: implications for management of pandemic influenza and other airborn infections. Health Technol Assess 2010; 14(46):131-172.

109. Seitz T, Deitchman S. Health Hazard Evaluation Report: NIOSH Evaluation 1992;90-140. http://www.cdc.gov/niosh/hhe/reports/ pdfs/1990-0140-2221.pdf. Accessed February 1, 2012.

110. Dimich-Ward H, Wymer ML, Chan-Yeung M. Respiratory health survey of respiratory therapists. Chest 2004;126(4):1048-1053.

111. Carnathan B, Martin B, Colice G. Second hand (S)-albuterol: RT exposure risk following racemic albuterol (abstract). Respir Care 2001;46(10):1084.

112. Christiani DC, Kern DG. Asthma risk and occupation as a respiratory therapist. Am Rev Respir Dis 1993;148(3):671-674.

113. Cochrane G, Bosley C. Compliance with inhaled therapy in asthma Eur Respir Rev 1994;4:92-94.

114. Guidry GG, Brown WD, Stogner SW, George RB. Incorrect use of metered dose inhalers by medical personnel. Chest 1992;101(1): 31-33.

115. Alvine GF, Rodgers P, Fitzsimmons KM, Ahrens RC. Disposable jet nebulizers. How reliable are they? Chest 1992;101(2):316-319.

116. Merkus P, van Essen-Zandlilet E, Parievliet E, Borsboom G, Sterk $\mathrm{P}$, Kerrebijn K. Changes of nebulizer output over the years. Eur Respir J 1992;5(4):488-491.

117. Snell N. Adverse reactions to inhaled drugs. Respir Med 1990; 84(5):345-348

118. Leuppi JD, Schnyder P, Hartmann K, Reinhart WH, Kuhn M. Druginduced bronchospasm: analysis of 187 spontaneously reported cases. Respiration 2001;68(4):345-351.

119. Babu KS, Marshall BG. Drug-induced airway diseases. Clin Chest Med 2004;25(1):113-122.

120. Walia M, Paul L, Satyavani A, Lodha R, Kalaivani M, Kabra SK. Assessment of inhalation technique and determinants of incorrect performance among children with asthma. Pediatr Pulmonol 2006; 41(11):1082-1087.

121. Steckel H, Eskandar F. Factors affecting aerosol performance during nebulization with jet and ultrasonic nebulizers. Eur J Pharm Sci 2003;19(5):443-455

122. O'Callaghan C, Barry PW. The science of nebulised drug delivery. Thorax 1997;52(Suppl 2):S31-S44.

123. Ip AY, Niven RW. Prediction and experimental determination of solute output from a Collison nebulizer. J Pharm Sci 1994;83(7): 1047-1051.

124. Tablan OC, Anderson LJ, Besser R, Bridges C, Hajjeh R. Guidelines for preventing health care-associated pneumonia 2003. Recommendations of the CDC and the Healthcare Infection Control Practices Advisory Committee. MMWR Morb Mortal Wkly Rep 2004;53(RR-3):1-36.

125. Sly R. Aerosol therapy in children. Respir Care 1991;36(9):9941007.

126. Rau JL. The inhalation of drugs: advantages and problems. Respir Care 2005;50(3):367-382.

127. Rubin BK, Durotoye L. How do patients determine that their metered-dose inhaler is empty? Chest 2004;126(4):1134-1137.

128. Berg E, Picard R. In-vitro delivery of budesonide from 30 jet nebulizer/compressor combinations using infant and child breathing patterns. Respir Care 54(12):1671-1678, 2009.

129. Phipps P, Gonda I. Droplets produced by medical nebulizers. Some factors affecting their size and solute concentration. Chest 1990; 97(6):1327-1332.

130. Dolovich M. Clinical aspects of aerosol physics. Respir Care 1991; 36(9):931-938.

131. Mason J, Miller W, Small S. Comparison of aerosol delivery via Circulaire system vs conventional small volume nebulizer. Respir Care 1994;39(12):1157-1161.
132. Agnew J. Characterizing lung aerosol penetration. J Aerosol Med 1991:4:237-249.

133. Restrepo RD, Dickson SK, Rau JL, Gardenhire DS. An investigation of nebulized bronchodilator delivery using a pediatric lung model of spontaneous breathing. Respir Care 2006;51(1):56-61.

134. Hess D, Fisher D, Williams P, Pooler S, Kacmarek RM. Medication nebulizer performance. Effects of diluent volume, nebulizer flow, and nebulizer brand. Chest 1996;110(2):498-505.

135. Silverman M. Aerosol therapy in the newborn. Arch Dis Child 1990;65(8):906-908.

136. Salmon B, Wilson N, Silverman M. How much aerosol reaches the lungs of wheezy infants and toddlers? Arch Dis Child 1990;65(4): 410-413.

137. Iles R, Lister P, Edmunds AT. Crying significantly reduces absorption of aerosolised drug in infants. Arch Dis Child 1999;81(2):163165.

138. Everard ML. Trying to deliver aerosols to upset children is a thankless task. Arch Dis Child 2000;82(5):428.

139. Janssens HM, van der Wiel EC, Verbraak AF, de Jongste JC, Merkus PJ, Tiddens HA. Aerosol therapy and the fighting toddler: is administration during sleep an alternative? J Aerosol Med 2003;16(4): 395-400.

140. Bowton D, Goldsmith W, Haponik E. Substitution of metered-dose inhalers for hand-held nebulizers: success and cost savings in a large, acute-care hospital. Chest 1992;101(2):305-308.

141. Tenholder M, Bryson M, Whitlock W. A model for conversion from small volume nebulizer to metered dose inhaler aerosol therapy. Chest 1992;101(3):634-637.

142. Orens D, Kester L, Fergus L, Stoller J. Cost impact of metered dose inhalers vs small volume nebulizers in hospitalized patients: the Cleveland Clinic experience. Respir Care 1991;36(10):1099-1104.

143. Yuksel B, Greenough A, Maconochie I. Effective bronchodilator treatment by a simple spacer device for wheezy premature infants. Arch Dis Child 1990;65(7):782-785.

144. Osman L, Hyland M. Patient needs and medication styles in COPD. Eur Respir Rev 2005;14(96):89-92.

145. Zainudin B, Biddiscombe M, Tolfree S, Short M, Spiro S. Comparison of bronchodilator responses and deposition patterns of salbutamol inhaled from a pressurised metered dose inhaler, as a dry powder, and as a nebulised solution. Thorax 1990;45(6):469-473.

146. Wildhaber JH, Dore ND, Wilson JM, Devadason SG, LeSouëf PN Inhalation therapy in asthma: nebulizer or pressurized metered-dose inhaler with holding chamber? In vivo comparison of lung deposition in children. J Pediatr 1999;135(1):28-33.

147. Fok T, Lam K, Ng P, Leung TF, So HK, Cheung KL, Wong W. Delivery of salbutamol to nonventilated preterm infants by metered-dose inhaler, jet nebulizer, and ultrasonic nebulizer. Eur Respir J 1998;12(1):159-164

148. Mitchell JP, Nagel MW. Valved holding chambers (VHCs) for use with pressurised metered-dose inhalers (pMDIs): a review of causes of inconsistent medication delivery. Prim Care Respir J 2007;16(4): 207-214.

149. Janssens H, Heijnen E, de Jong V, Holland W, de Jongste J, Tiddens H. Aerosol delivery from spacers in wheezy infants: a daily life study. Eur Repir J 2000;16(5):850-856.

150. Shah S, Berlinski A, Rubin BK. Force-dependent static dead space of face masks used with holding chambers Respir Care 2006;51(2): 140-144.

151. Hayden J, Smith N, Woolf D, Barry P, O'Callaghan C. A randomised crossover trial of facemask efficacy. Arch Dis Child 2004; 89(1):72-73

152. Amirav I, Mansour Y, Mandelberg A, Bar-Ilan I, Newhouse M Redesigned face mask improves "real life" aerosol delivery for Nebuchamber. Pediatr Pulmonol 2004;37(2):172-177. 
153. Amirav I. Infant aerosol holding chamber face masks: not all are born equal! Respir Care 2006;51(2):123-125.

154. Janssens H, Tiddens H. Aerosol therapy: the special needs of young children. Pediatr Respir Rev 2006;7(Suppl 1):S83-S85.

155. Rubin BK. Bye-bye, blow-by (editorial). Respir Care 2007;52(8): 981.

156. Lin L, Restrepo RD, Gardenhire DS, Rau JL. Effect of face mask design on inhaled mass of nebulized albuterol, using a pediatric breathing model. Respir Care 2007;52(8):1021-1026.

157. Vidgren MT. Factors influencing lung deposition of inhaled aerosols. Eur Respir J 1994;4:68-70.

158. Kurosaka F, Nishio H. Comparison of the bronhodilative effects of salbutamol delivered via three mesh nebulizers in children with bronchial asthma Allergol Int 2009;58(4):529-535.

159. Dhuper S, Chandra A, Ahmed A, Bista S, Moghekar A, Verma R, et al. Efficacy and cost comparisons of bronchodilatator administration between metered dose inhalers with disposable spacers and nebulizers for acute asthma treatment. J Emerg Med 2011;40(3): 247-255.

160. Leversha AM, Campanella SG, Aickin RP, Asher MI. Costs and effectiveness of spacer versus nebuliser in young children with moderate and severe acute asthma. J Pediatr 2000(4):497-502.

161. Turner MO, Gafni A, Swan D, FitzGerald JM. A review and economic evaluation of bronchodilator delivery methods in hospitalized patients. Arch Intern Med 1996;156(18)2113-2118.

162. Jasper A, Monhsenifar Z, Kahan S, Goldberg H, Koerner S. Costbenefit comparison of aerosol bronchodilator delivery methods in hospitalized patients. Chest 1987;91(4):614-618.

163. Dhuper S, Chandra A, Ahmed A, Bista S, Moghekar A, Verma R. Efficacy and cost comparisons of bronchodilatator administration between metered dose inhalers with disposable spacers and nebulizers for acute asthma in an inner-city adult population. Am J Health Syst Pharm 2008;62(10):1053-1061.

164. Summer W, Elston R, Tharpe L, Nelson S, Haponik EF. Aerosol bronchodilator delivery methods. Relative impact on pulmonary function and cost of respiratory care. Arch Intern Med 1989;149(3): 618-623.

165. Salyer JW, DiBlasi RM, Crotwell DN, Cowan CA, Carter ER. The conversion to metered-dose inhaler with valved holding chamber to administer inhaled albuterol: a pediatric hospital experience. Respir Care 2008;53(3):338-345.

166. Hendeles L, Hatton RC, Coons TJ, Carlson L. Automatic replacement of albuterol nebulizer therapy by metered-dose inhaler and valved holding chamber. Am J Health Syst Pharm 2005;62(10): 1053-1061.

167. Kim SH, Kwak HJ, Kim TB, Chang YS, Jeong JW, Kim CW, et al. Inappropriate techniques used by internal medicine residents with three kinds of inhalers (a metered dose inhaler, Diskus, and Turbuhaler): changes after a single teaching session. J Asthma 2009; 46(9):944-950.

168. Cunha AJ, Santos MA, Galvão MG, Ibiapina AA. Knowledge of pediatricians in Rio de Janeiro, Brazil about inhalation therapy in asthmatic children. Allergol Immunopathol (Madr) 2003;31(2):87-90.

169. Self TH, Arnold LB, Czosnowski LM, Swanson JM, Swanson H. Inadequate skill of healthcare professionals in using asthma inhalation devices. J Asthma 2007;44(8):593-598.

170. Amirav I, Burg F. The need to educate health professionals about childhood asthma. Arch Pediatr Adolesc Med 1994;148(12):13391343.

171. Benjaponpitak S, Kraisarin C, Direkwattanachai C, Sasisakunporn C. Incorrect use of metered dose inhaler by pediatric residents. J Med Assoc Thai 1996;79(2):122-126.

172. Melani AS. Inhalatory therapy training: a priority challenge for the physician. Acta Biomed 2007;78(3):233-245.
173. Lewis RM, Fink JB. Promoting adherence to inhaled therapy: building partnerships through patient education. Respir Care Clin N Am 2001;7(2):277-301.

174. Akapo S, Gupta J, Martinez E, McCrea C, Ye L, Roach M. Compatibility and aerosol characteristics of formoterol fumarate mixed with other nebulizing solutions. Ann Pharmacother 2008;42(10): 1416-1424.

175. Kamin W, Schwabe A, Kramer I. Inhalation solutions: which one are allowed to be mixed? Physico-chemical compatibility of drug solutions in nebulizers. J Cyst Fibros 2006;5(4):205-213.

176. Burchett D, Darko W, Zahra J, Noviasky J, Probst L, Smith A. Mixing and compatibility guide for commonly used aerosolized medications. Am J Health Syst Pharm 2010;67(3):227-230.

177. Hagmolen of ten Have W, van de Berg N, Bindels P, van Aalderen W, van der Palen J. Assessment of inhalation technique in children in general practice:increased risk of incorrect performance with new device. J Asthma 2008;45(1):67-71.

178. Rubin BK. What does it mean when a patient says, "My asthma medication is not working"? Chest 2004;126(3):972-981.

179. Deerojanawong J, Promsaka na Sakolnakorn V, Prapphal N, Hanrutakorn C, Sritippayawan S. Evaluation of metered-dose inhaler administration technique among asthmatic children and their caregivers in Thailand. Asian Pac J Allergy Immunol 2009;27(2-3):8793.

180. Lavorini F, Levy ML, Dekhuijzen PN, Crompton GK. Inhaler choice and inhalation technique: key factors for asthma control. Prim Care Respir J 2009;18(4):241-242.

181. Lavorini F, Magnan A, Dubus JC, Voshaar T, Corbetta L, Broeders $\mathrm{M}$, et al. Effect of incorrect use of dry powder inhalers on management of patients with asthma and COPD. Respir Med 2008; 102(4):593-604.

182. Caldwell N. Nebulization in hospitals and home: standardizing the variables. Eur Respir Rev 1994;4:99-101.

183. Burgess S, Sly P, Devadason S. Providing feedback on adherence increases use of preventive medication by asthmatic children. J Asthma 2010;47(2):198-201.

184. Brand PL, van der Baan-Slootweg OH, Heynens JW, de Vries TW, Versteegh FG, Vreuls RC, et al. Comparison of handling and acceptability of two spacer devices in young children with asthma. Acta Paediatr 2001;90(2):133-136.

185. O'Malley CA, VandenBranden SL, Zheng XT, Polito AM, McColley SA. A day in the life of a nebulizer: surveillance for bacterial growth in nebulizer equipment of children with cystic fibrosis in the hospital setting. Respir Care 2007;52(3):258-262.

186. Saiman L, Siegel J. Infection control recommendations for patients with cystic fibrosis: microbiology, important pathogens, and infection control practices to prevent patient-to-patient transmission. Am J Infect Control 2003;31(3):S6-S62.

187. Centers for Disease Control and Prevention. Guideline for prevention of nosocomial pneumonia. Respir Care 1994;39(12):1191-1236.

188. US Food and Drug Administration. Public Health Advisory: Contamination of multi-dose bottles of albuterol sulfate solution for inhalation (0.5\%). April 19, 2002. http://www.fda.gov/Drugs/DrugSafety/ PostmarketDrugSafetyInformationforPatientsandProviders/DrugSafety InformationforHeathcareProfessionals/PublicHealthAdvisories/ucm 170883.htm. Accessed February 1, 2012.

189. Guyatt G, Oxman A, Vist Gea. GRADE: an emerging consensus on rating quality of evidence and strength of recommendations. BMJ 2008;336(7650):924-926.

190. Jaeschke R, Guyatt G, Dellinger P, Schünemann H, Levy M, Kunz Rea. Use of GRADE grid to reach decisions on clinical practice guidelines when consensus is elusive. BMJ 2008;337:a744. DOI: 10.1136/bmj.a744. 